\title{
Economic Assesment and Socio-Economic Evaluation of Water Use Efficiency in Artichoke Cultivation
}

\author{
José García García $^{1^{*}}$, Fulgencio Contreras López ${ }^{1}$, Domenico Usai ${ }^{2}$, Caterina Visani ${ }^{2}$ \\ ${ }^{1}$ Instituto Murciano de Investigación y Desarrollo Agrario y Alimentario (IMIDA), Estación Sericícola, La Alberca, Spain \\ ${ }^{2}$ Laore Sardegna, Cagliari, Italy \\ Email: jose.garcia21@carm.es
}

Received December 31, 2012; revised February 10, 2013; accepted March 3, 2013

Copyright (C) 2013 José García García et al. This is an open access article distributed under the Creative Commons Attribution License, which permits unrestricted use, distribution, and reproduction in any medium, provided the original work is properly cited.

\begin{abstract}
The aim of this work is to provide a methodology for analysing socioeconomic aspects of water resource management that will provide with an objective decision making tool. To validate the proposed analysis method here, we refer to three artichoke production options. The economic evaluations indicate that the drip irrigation systems are viable and profitable. The traditional method of flooding is not a viable option despite needing the lowest investment, but is close to the viability threshold. In reference to water use efficiency, option 1 is by far the most effective $\left(3.60 \mathrm{~kg} \cdot \mathrm{m}^{-3} \mathrm{com}-\right.$ pared with 2.25 and $2.18 \mathrm{~kg} \cdot \mathrm{m}^{-3}$, respectively). In our analysis we find that the most productive systems generate the most employment per unit of surface area. Option 1 is the most competitive in relation with the water factor, since it could support prices up to $0.53 € \cdot \mathrm{m}^{-3}$ and still be economically viable. System 2 will not be viable if the price exceeds $0.22 € \cdot \mathrm{m}^{-3}$. Option 3 is viable up to $0.17 € \cdot \mathrm{m}^{-3}$, which is more than is paid at the present time in Sardinia, although such an option would not be viable in south-eastern Spain.
\end{abstract}

Keywords: Cost-Benefit Analysis; WUE; Water Viability Threshold (WVT); Water Productivity

\section{Introduction}

Throughout the Mediterranean Basin, water is an important production factor and an economic benefit, whose commercial value differs from that of normal market goods. This differences lies in the fact that it is the good's use, in this case, that has the value and it is not possible to speak of its final nor-long term appropriation. The use of which water is put in linked to production processes, for example agriculture, which has a clear economic significance. It is customary to avoid speaking of the price of water and to allude to expressions like the cost associated with the resource, etc. However, from an economic point of view, since water is a commercial object, there is nothing wrong with speaking of its price. If we accept this, it is possible to construct an economic theory for each use and, within these, each of the associated productive activities, which justifies the decisions taken for assigning water resources when these are the object of competition between various activities. Therefore, the application of economic theory to water use and the economic analysis of the activities in which this resource intervenes, in the area that concerns us, which

\footnotetext{
"Corresponding author.
}

must involve political recommendations for the best public use of water [1].

In recent years several authors [2-4], in reference to south eastern Spain, have proposed different economic or socio-economic water use indices with regard to a variety of crops - such as the benefit $/ \mathrm{m}^{3}$ or paid employee $/ \mathrm{m}^{3}$ and have pointed to the need for economic studies that can serve as decisions-making tools at microeconomic level, and planning at the macroeconomic level. Such an economic analysis has to be made bearing in mind global economic efficiency, not merely technical or productive efficiency. Looking at irrigated productive systems from a global viewpoint, the use of costs analysis systems [5-8] is recommendable to evaluate the relative importance of given variables linked to production and their repercussion on economic indices that may serve to establish economic and environmental viability criteria. This is a question of rationalising the use of resources and, especially, of reducing the use of scarce and limiting natural resources such as water, or diminishing the use of other, potentially contaminating resources. In this sense, many studies have been dedicated to evaluating water use efficiency (WUE) from a productive stance [7,9-12], but few 
have tried to evaluate the same from a social or economic point of view [8,13-14], which may be regarded as an important lacuna.

In the specific case of the cost of water, the variety of prices that is so common in deficient basins, which is basically due to the great variety of the origin of the water (superficial, subterranean, residual, desalinated, etc.) makes it even more necessary to establish viability and profitability thresholds with respect to this production factor [8].

The aim of this work is to provide a methodology for analysing socio-economic aspects of water resource management that will provide with an objective decision making tool. To validate the proposed analysis method here, we refer to three artichoke production options. The methodology we set out has two stages: 1) Economic assessment through a cost benefit analysis, and 2) Water use efficiency assessment.

The efficiency in the use of a resource (input) should be done from a global perspective, i.e., productive and economic, and we do it through cost benefit analysis indicators as well as through water efficiency indicators. In this sense, we use indicators of productivity, economic and even social. We do it for a complete economic analysis.

The exercise falls within the framework of the European Novagrimed project, co-financed by the EU programme, MED, for encouraging international cooperation. Given that water management in the south of Europe is special because of the imbalance between supply and demand, which has socio-economic implications, regions associated with the project have shown interest in applying a socio-economic analysis model (henceforth SEAM) to their particular cases. As partners, Sardinia (Italy) and Murcia (SE Spain) established artichoke as a representative crop for both regions. Italy, with 50,000 hectares is the world's leading producer followed by Spain with 20,000 hectares under cultivation. In Italy, Sardinia has $25 \%$ of the cultivated area. Production in Spain is based mainly on the Mediterranean coast, with Murcia and the southeast being the main areas of cultivation, accounting for over $60 \%$ of total production [15].

\section{Methodology}

For the correct application of SEAM to each local system, the production and marketing structure of a given crop has to be determined. Production costs do not only depend on the crop, but on the type of agrarian set-up as a whole: irrigation system, exploitation size, cultivation techniques, etc. Similarly, incomes will depend on marketing systems, which are frequently specific to one area. Therefore, establishing the characteristics of a represen- tative exploitation for a given zone is essential. To validate the proposed analysis method here, for example, we refer to three production options: two in Murcia, one drip irrigated (option 1) and the other irrigated by the traditional method of flooding (option 2), and one in the north of Sardinia, also drip irrigated (option 3). This will enable comparisons between two European regions and two irrigation systems.

We study an average production year, using data obtained from the exploitations of both areas by questionnaire and other data concerning production provided by public sector technicians working in the field of agrarian production: in Murcia from the Oficinas Comarcales Agrarias and Centros Integrados de Capacitación y Experiencias Agrarias, both belonging to the Local Government Department of Agriculture, and, in Sardinia, the Agencia Laore Sardegna. The information was obtained by in situ questionnaires in three stages: an open interview with the growers, followed by a questionnaire designed by us (IMIDA) given to the same. The questionnaire asked for information on the production system and corresponding investment, production yield indicators, workforce employed and other production costs. Lastly, the information was validated by asking specific questions.

Using costs analysis, the costs structure of each exploitation type was described and socio-economic indices and parameters were determined, applying microeconomic analysis to costs accounting [16-18]. To calculate costs, productive variables extracted from the questionnaires were used (Table 1). The costs were divided into fixed assets and operating costs. The fixed assets costs are reflected in Tables 2-4 in the case of productive options 1, 2 and 3, respectively. The useful life calculated was based on the experience of growers covering recent years for each area as real half life. Tables 2-4 show the initial investments, depreciation of each element calculated by the linear method or constant quotas.

To calculate the employment generated, the workforce employed in the different tasks, including operating machinery was calculated. In Murcia, one unit of agricultural work or number of agricultural jobs (NAJ) corresponds to 1800 hours, while in Sardinia it is 1560 hours. In both places the net daily salary is 56 Euros including social security costs.

In Murcia growers receive water from their corresponding Comunidades de Regantes (water users association) the cost of the same varying with the amount consumed and the price established each year by the association (mean price for the last three years, $0.23 € \cdot \mathrm{m}^{-3}$ ). The irrigators of Sardinia receive water form their corresponding Consorzio de Bonifica, which normally establishes prices as a function of allocation per surface area and type of crop. In the study area the allocated module 
Table 1. Technical and economic variables of each productive option.

\begin{tabular}{cccc}
\hline & Option 1 & Option 2 & Option 3 \\
\hline Irrigation system & Drip irrigation & Flooding & Drip irrigation \\
Average explotaition size (ha) & 4 & 2.5 & 10 \\
Planting density (plants/ha) & 12,500 & 12,000 & 8000 \\
Production $(\mathbf{k g} / \mathbf{h a})$ & 18,000 & 18,000 & $36,000^{*}$ \\
Water consumption $\left(\mathbf{m}^{\mathbf{3}} / \mathbf{h a )}\right.$ & 5000 & 8000 & 3750 \\
Price of water $\left(\mathbf{\epsilon} / \mathbf{m}^{\mathbf{3}}\right)$ & 0.23 & 0.23 & 0.07 \\
Farm tenancy $(\boldsymbol{G} / \mathbf{h a} \cdot \mathbf{a n ̃ o})$ & 700 & 750 & 800 \\
Crop insurance $(\mathbf{\epsilon} / \mathbf{h a} \cdot \mathbf{a n ̃ o})$ & - & - & 750 \\
\hline
\end{tabular}

*It is marketed by units ( $1 \mathrm{~kg}=4.4$ units): 36,000 units equivalent to $8182 \mathrm{~kg}$. Average annual rainfall: Campo de Cartagena (Murcia) - $320 \mathrm{~mm}$; Valle del Guadalentín-322 mm; Valledoria (Sardegna)-704 mm.

Table 2. Investment and annual depreciation in artichoke crop. Campo de Cartagena (España). Option 1.

\begin{tabular}{|c|c|c|c|c|}
\hline & Initial value $(€)$ & Residual value $(€)$ & Useful life (years) & Depreciation $^{*}\left(€ \cdot\right.$ year $\left.^{-1}\right)$ \\
\hline Shed for equipment and irrigation control & 9000 & 1800 & 25 & 294 \\
\hline Irrigation equipment & 9000 & 0 & 15 & 612 \\
\hline Irrigation network $^{*}$ & 5500 & 0 & 8 & 701 \\
\hline Planting & 13,372 & 0 & 2 & 6820 \\
\hline Reservoir & 15,000 & 3750 & 30 & 383 \\
\hline Various & 300 & 0 & 5 & 61 \\
\hline Investment (4 ha) & & & 52,172 & \\
\hline
\end{tabular}

*Annual depreciation plus opportunity cost (2\%).

Table 3. Investment and annual depreciation in artichoke crop. Valle del Guadalentín (España). Option 2.

\begin{tabular}{|c|c|c|c|c|}
\hline & Initial value $(€)$ & Residual value $(€)$ & Useful life (years) & Depreciation $^{*}\left(€ \cdot\right.$ year $\left.^{-1}\right)$ \\
\hline Shed for equipment and irrigation control & 5400 & 1080 & 25 & 176 \\
\hline Irrigation equipment & 0 & 0 & 15 & 0 \\
\hline Irrigation network $^{*}$ & 0 & 0 & 8 & 0 \\
\hline Planting & 9493 & 0 & 2 & 4841 \\
\hline Reservoir & 0 & 0 & 30 & 0 \\
\hline Various & 188 & 0 & 5 & 38 \\
\hline Investment (2.5 ha) & & & 15,080 & \\
\hline
\end{tabular}

*Annual depreciation plus opportunity cost (2\%).

Table 4. Investment and annual depreciation in artichoke crop. Valledoria (Cerdeña-Italia). Option 3.

\begin{tabular}{ccccc}
\hline & Initial value $(€)$ & Residual value $(€)$ & Useful life (years) & Depreciation $^{*}\left(€ \cdot\right.$ year $\left.^{-1}\right)$ \\
\hline Shed for equipment and irrigation control & 35,000 & 7000 & 25 & 1142 \\
Irrigation equipment & 3000 & 0 & 15 & 204 \\
Irrigation network $^{*}$ & 24,530 & 0 & 8 & 3128 \\
Planting & 20,970 & 0 & 1 & 21,389 \\
Reservoir & 0 & 0 & 30 & 0 \\
Various & 1000 & 0 & 5 & 204 \\
Investment (10 ha) & & & 84,500 \\
\hline
\end{tabular}

\footnotetext{
*Annual depreciation plus opportunity cost $(2 \%)$
} 
by the Consorzio de Bonifica of Nord Sardegna is 240 $€ \cdot$ ha $^{-1}$, which implies a fixed cost associated with crop area and so this cost can be translated into a price per $\mathrm{m}^{3}$ water used.

Total incomes are calculated taking into account the mean selling price per kilo for the period 2000-2010 obtained from the respective Agrarian Statistical Services for each region studied. The viability threshold represents the minimum price per kilo that makes the activity viable, or, what is the same, the mean production cost. The break even point identifies the minimum production (for a selling price) that is compatible with the viability of the activity, expressed as $\mathrm{kg}$ ha or minimum number of hectares.

The other indices determined for use in the analysis of irrigation water efficiency were water production efficiency, expressed as $\mathrm{kg}$ of production $\mathrm{m}^{-3}[13,14]$, net margin $\mathrm{m}^{-3}$ and economic efficiency and salaried personnel per cubic hectometre or social efficiency (number of agricultural jobs, NAJ $\cdot \mathrm{hm}^{-3}$ ). Lastly, the maximum price of irrigation water above which the exploitation begins to generate positive results or water viability threshold (WVT) was calculated [7,19]. WVT is defined as the water price for which $\mathrm{NM}=0$, so $\mathrm{I}=\mathrm{C}$; thus, it is the maximum price compatible with the economical viability.

As an indicator of the social importance of water, the number of employed for each $\mathrm{hm}^{3}$ of water consumed for cultivation. The NAJ $\cdot \mathrm{ha}^{-1}$ and NAJ $\cdot \mathrm{hm}^{-3}$ were calculated to estimate the social importance of the sector. The indicators NAJ $\cdot \mathrm{hm}^{-3}$ shows the level of employment per $\mathrm{hm}^{3}$ and is also an indicator of the employment generated by the irrigation water resource. This social efficiency value of irrigation water, proposed by some authors as a relation between the employment generated and the water consumed by the crop in question [13], has been used in specific studies such as that of [3] on fruit trees in the region of Murcia.

\section{Results and Discussion}

\subsection{Cost Accounting}

First, Table 5 shows the cost accounting of the production unit established for each option as an absolute value and in relative terms, and demonstrates the relative importance of each of the costs. The costs structure shows an intensive system with high fixed assets $(22 \%-30 \%)$. All the production options involve investment and therefore a high fixed asset compared with other woody crops, basically due to the fact that these have a useful life of longer than 20 years in most cases. For example, for an orange plantation, [20] found fixed assets of $10.6 \%$ and $12.3 \%$ for control (100\% ETc) and deficit irrigation systems, respectively; similarly, [7] calculated fixed assets of $10.0 \%$ for a control irrigation of almonds and $12.0 \%$ for RDI. As can be seen, the fixed assets costs are substantially below those calculated in the present work $(22 \%-30 \%)$ for a horticultural crop, artichoke, the infrastructure associated with drip irrigation being responsible for these higher costs (Table 5). Studies dealing with costs accounting in artichoke are practically non-existent. One of the few is that of [21], also in the Campo de Cartagena of the province of Murcia, like our option 1, the mean investment was $2154 € \cdot \mathrm{ha}^{-1}$, which is very close to our value of $2208 € \cdot \mathrm{ha}^{-1}$ (Table 5).

The greatest relative cost associated with fixed assets is planting (including the cost of the plants) in all the systems, especially in option 3 , where it represents almost $25 \%$ of the total (the cycle was only one year in this case).

Of great importance in operating costs was the cost of water. The two drip irrigation systems involved a large difference in this respect, option 3 showing a relative cost for irrigation of $2.96 \%$, which rose to $13.57 \%$ in option 1. This was due to the much higher contribution of rainwater in option 3 (less need for irrigation), but especially to the great difference in the price of irrigation water in option 1 it was $0.23 € \cdot \mathrm{m}^{-3}$ and only $0.07 € \cdot \mathrm{m}^{-3}$ in option 3. In turn, the cost of water in option 2 reached $20 \%$ due to the high consumption of the same (Table 5), which reflects the inefficiency of flooding as cultivation practice. The cost of water was the same as in option 1 $\left(0.23 € \cdot \mathrm{m}^{-3}\right)$.

In south-eastern Spain, and particularly in Murcia, the structural scarcity of this important resource makes it a limiting factor for agricultural production and its price also varies considerably [3]. The price of water (from the Tajo-Segura transfer system) used in this study was the same as it is at present, although it can reach $0.26 € \cdot \mathrm{m}^{-3}$ [22]. However, subterranean and desalinated water (costing more than $0.33 \mathrm{~m}^{3}$ ) is sometimes used to compensate for the deficit in supply. Also of note is the similarity and importance of the farm tenancy (hiring) and harvesting costs in the three systems-about $9 \%$ and $25 \%$ of the production costs, respectively.

\subsection{Cost-Benefit Analysis}

Table 6 contains the indicators used in the comparative economic analysis. The respective economic evaluations indicate that the drip irrigation systems are economically viable and profitable. The traditional method of flooding is not a viable option despite needing the lowest investment, but is close to the viability threshold $(\mathrm{NM}=0)$. The profitability indicators are highest for option 1 despite having the highest mean investment (Table 2). This option has the highest short term profitability, which is a high NM/C (24.53\%), although its long term profitability, 
Table 5. Cost accounting for all options.

\begin{tabular}{|c|c|c|c|c|c|c|}
\hline & \multicolumn{2}{|l|}{ Option 1} & \multicolumn{2}{|l|}{ Option 2} & \multicolumn{2}{|l|}{ Option 3} \\
\hline & Absolute cost $(€)$ & Relative cost (\%) & Absolute cost $(€)$ & Relative cost $(\%)$ & Absolute cost $(€)$ & Relative cost (\%) \\
\hline Shed & 294 & 0.85 & 176 & 0.76 & 1142 & 1.33 \\
\hline Irrigation equipment & 680 & 1.77 & 0 & 0.00 & 204 & 0.24 \\
\hline Irrigation network & 701 & 2.03 & 0 & 0.00 & 3128 & 3.63 \\
\hline Planting & 6820 & 19.72 & 4841 & 20.90 & 21,389 & 24.83 \\
\hline Reservoir & 383 & 1.11 & 0 & 0.00 & 0 & 0.00 \\
\hline Various & 61 & 0.18 & 38 & 0.17 & 204 & 0.24 \\
\hline Fixed assets & 8832 & 25.65 & 5056 & 21.83 & 26,067 & 30.25 \\
\hline Manual weeding & 449 & 1.30 & 219 & 0.94 & 196 & 0.23 \\
\hline Machinery & 1071 & 3.10 & 1148 & 4.95 & 6197 & 7.19 \\
\hline Phytosanitary products & 1958 & 5.66 & 1255 & 5.42 & 3302 & 3.83 \\
\hline Fertilizers & 2717 & 7.86 & 1101 & 4.75 & 3580 & 4.16 \\
\hline Herbicides & 306 & 0.88 & 287 & 1.24 & 638 & 0.74 \\
\hline Maintenance & 240 & 0.69 & 55 & 0.24 & 638 & 0.74 \\
\hline Farm tenancy & 2856 & 8.26 & 1913 & 8.26 & 8160 & 9.47 \\
\hline Electricity & 364 & 1.05 & 0 & 0.00 & 0 & 0.00 \\
\hline Fixed staff & 2244 & 6.49 & 1403 & 6.06 & 7344 & 8.52 \\
\hline Crop insurance & 0 & 0.00 & 0 & 0.00 & 7650 & 8.88 \\
\hline Harvesting & 8813 & 25.48 & 6036 & 26.06 & 19,839 & 23.03 \\
\hline Irrigation & 4692 & 13.57 & 4692 & 20.26 & 2550 & 2.96 \\
\hline Operating costs & 25,710 & 74.35 & 18,107 & 78.17 & 60,093 & 69.75 \\
\hline Total cost $(€)$ & 34,581 & $100 \%$ & 23,162 & $100 \%$ & 86,160 & $100 \%$ \\
\hline Unit cost $\left(€ \cdot \mathbf{h a}^{-1}\right)$ & $8645^{*}$ & & $9265^{*}$ & & $8616^{*}$ & \\
\hline
\end{tabular}

"Production cost per hectare.

Table 6. Indexes of economic assessment.

\begin{tabular}{cccccc}
\hline Option & $\mathrm{NM} / \mathrm{K}_{0}(\%)$ & $\mathrm{NM} / \mathrm{c}(\%)$ & $\mathrm{NM} / \mathrm{C}(\%)$ & Production cost $\left(€ \cdot \mathrm{kg}^{-1}\right)$ & Break even point $\left(\mathrm{kg} \cdot \mathrm{ha}^{-1}\right)$ \\
\hline Option 1 & 12.09 & 24.53 & 18.24 & 0.48 & 15,223 \\
Option 2 & -1.41 & -1.17 & -0.91 & 0.51 & 18,166 \\
Option 3 & 4.54 & 6.39 & 4.46 & 1.05 & 7833 \\
\hline
\end{tabular}

Abbreviations: $\mathrm{NM} / \mathrm{K}_{0}$, net margin/ investmet; $\mathrm{NM} / \mathrm{c}$, net margin/operating cost; $\mathrm{NM} / \mathrm{C}$, net margin/total cost.

expressed as $\mathrm{NM} / \mathrm{K}_{0}(12.09 \%)$, is relatively low since investment is high. Whatever the case, the overall profitability expressed as $\mathrm{NM} / \mathrm{C}$ is $18.24 \%$ compared with $-0.91 \%$ and $4.46 \%$, respectively. The cost of production is the mean price of each unit produced and, in this sense, option 1 was the most efficient at $0.48 € \cdot \mathrm{kg}^{-1}$, which is very similar to the value $0.44 € \cdot \mathrm{kg}^{-1}$ obtained by [21] in the same growing area. Option 2 had a very similar value $\left(0.51 € \cdot \mathrm{kg}^{-1}\right)$, whereas option 3 must be considered very unproductive ( $8182 \mathrm{~kg} \cdot \mathrm{ha}^{-1}$, Table 1) and every kilo produced cost $1.05 €$, which is equivalent to $0.24 €$ per unit (in this case individual artichokes, not kilos, are marketed). Lastly, the break even point $(\mathrm{NM}=0)$ points to the minimum productivity for an average exploitation, which was $15,223,18,166$ and $7833 \mathrm{~kg} \cdot \mathrm{ha}^{-1}$ for the three options, respectively. The break even point can also identify the minimum size for an exploitation to be viable using the production variables described $(3.38,2.52$ and 9.57 hectares, respectively). In other words, option 1 was of sufficient size, option 2 was only just viable and option 3 was sufficient in size but only relatively large exploitations are economically viable ( $>9.57 \mathrm{ha}$ ). 


\subsection{Assessment of Water Use Efficiency}

Lastly, the indicators destined for the analysis of water use efficiency are shown in Table 7. The water use efficiency index (WUE) is the most widely used index in the bibliography on water efficiency. It is usually measured in $\mathrm{kg}$ of crop per mm irrigation water used or $\mathrm{kg} / \mathrm{m}^{3}$. For example, in almond, [7,9] mention the WUE in southeastern Spain and California, respectively, while the WUE for peach cultivation is described by [23] in California and [10] in Italy. The vineyard WUE values obtained in [24] for PRD and RDI or those obtained by [8] for various irrigation strategies should also be mentioned. Many studies have looked at the WUE and dry matter production in herbaceous crops [11,12]. In our case (Table 7), option 1 is by far the most effective (3.60 $\mathrm{kg} \cdot \mathrm{m}^{-3}$ compared with 2.25 and $2.18 \mathrm{~kg} \cdot \mathrm{m}^{-3}$, respectively). The gross economic productivity of water has also been used (Table 7), but less frequently. For example, [25] describe how in California water productivity (WP) is $0.20 € \cdot \mathrm{m}^{-3}$ for maize, $0.70 € \cdot \mathrm{m}^{-3}$ for almond and $5.00 € \cdot \mathrm{m}^{-3}$ for strawberry; [4] in peach calculated a figure of around $2.40 € \cdot \mathrm{m}^{-3}$, depending on the variety in question.

These indices are valid but do not provide a full picture of the social and economic efficiency of water, which are as important as the productive efficiency. In other words, an irrigation strategy may be productively efficient but not economically so, while it would seem evident that benefit per unit of resource should also be maximised $\left(\mathrm{NM} \cdot \mathrm{m}^{-3}\right)$. In this way, the economic efficiency can be calculated from the costs and incomes associated with each type of productive system analysed. For example, in vine, [8] found that deficit treatments could provide a WUE of up to $7.19 \mathrm{~kg} \cdot \mathrm{m}^{-3}$ but are economically unviable and present negative economic efficiency. In contrast, the control treatment had a lower WUE $\left(5.90 \mathrm{~kg} \cdot \mathrm{m}^{-3}\right)$ but an economic efficiency of 0.31 $€ \cdot \mathrm{m}^{-3}$. This index has been little used until now but we think it may be useful at exploitation level or for planning and management irrigation strategies [8,14,18,26, 27]. The use of $\mathrm{NM} \cdot \mathrm{m}^{-3}$ as economic efficiency index is assimilable to a benefit generated per $\mathrm{m}^{3}$. In the three options analysed we see that only drip irrigation systems generate a positive index, with option 1 standing out for its WUE of $0.22 € \cdot \mathrm{m}^{-3}$, which is much higher than the values cultivated for herbaceous crops such as rice $(0.02$ $\left.€ \cdot \mathrm{m}^{-3}\right)$ or grain corn $\left(0.034 € \cdot \mathrm{m}^{-3}\right)$ [28].

It is unusual to use social criteria in the evaluation of water use efficiency, and such criteria are normally confined to agricultural planning policies [29,30]. They are, for example, used in European Comission documents referring to the agricultural sector [31] and in hydrological planning, as in the report published on the hydrological and socio-economic situation of the Segura Basin in the Spanish National Hydrological Plan-Plan Hidrológico Nacional [32] — where water productivity and direct employment generated per cubic metre are discussed. In the document it is maintained that water use efficiency in the Segura Basin is maximal at $24-62 \mathrm{NAJ} \cdot \mathrm{hm}^{-3}$ for horticulture and fruit crops and up to $190 \mathrm{NAJ} \cdot \mathrm{hm}^{-3}$ for greenhouse grown crops. The same report estimates the average gross incomes per cubic metre of irrigation water are $0.91 € \cdot \mathrm{m}^{-3}$ for irrigated crops as a whole in the province of Murcia.

We propose that two criteria could be used: NAJ $\cdot \mathrm{ha}^{-1}$ and NAJ $\cdot \mathrm{hm}^{-3}$. The former quantifies the employment generated by a crop in its primary phase (production and harvesting) and could be widened to subsequent phases of the production process (handling, packaging and transport). The latter, which estimates the employment generated per $\mathrm{hm}^{3}$ of water consumed, is clearly an indicator of the social efficiency of water.

In our analysis we find that the most productive systems are those which generate the most employment per unit of surface area, especially employment related with the work force needed for harvesting. Whatever the case, all three options generate substantial employment (0.17 $0.22 \mathrm{NAJ} \cdot \mathrm{ha}^{-1}$, only considering production and harvesting), compared with other systems such as irrigated vine (0.12) or agricultural activity in general (0.05) [31]. In turn, the social efficiency of water is much higher in drip irrigation systems which consume relatively low quantities of water, reaching $45 \mathrm{NAJ} \cdot \mathrm{hm}^{-3}$ in option 3 .

Lastly, the WVT is the maximum price that can be paid for water if the activity is to be economically viable. This is a very important factor in arid or semiarid areas,

Table 7. Indexes of water use efficiency.

\begin{tabular}{ccccccc}
\hline Option & Productivity $\left(€ \cdot \mathrm{m}^{-3}\right)$ & $\begin{array}{c}\text { Productive effciciency } \\
\left(\mathrm{kg} \cdot \mathrm{m}^{-3}\right)\end{array}$ & $\begin{array}{c}\text { Economic efficiency } \\
\left(€ \cdot \mathrm{m}^{-3}\right)\end{array}$ & $\mathrm{NAJ} \cdot \mathrm{ha}^{-1}$ & $\mathrm{NAJ} \cdot \mathrm{hm} \mathrm{m}^{-3}$ & $\mathrm{WVT}\left(€ \cdot \mathrm{m}^{-3}\right)$ \\
\hline Option 1 & 2.04 & 3.60 & 0.32 & 0.22 & 44 & 0.53 \\
Option 2 & 1.15 & 2.25 & -0.01 & 0.21 & 26 & 0.22 \\
Option 3 & 2.40 & 2.18 & 0.10 & 0.17 & 45 & 0.17 \\
\hline
\end{tabular}

Abbreviations: NAJ'ha ${ }^{-1}$, number of agricultural jobs per hectare; NAJ'hm ${ }^{-3}$, number of agricultural jobs per cubic hectometre; WVT, water viability threshold. 
where water is scarce and increasingly expensive. This index can indicate what crops or irrigation strategies will result competitive at a given price for water. In our case, option 1 is the most competitive in relation with the water factor, since it could support prices up to $0.53 € \cdot \mathrm{m}^{-3}$ and still be economically viable. System 2 will not be viable if the price exceeds $0.22 € \cdot \mathrm{m}^{-3}$, which is already the case in the study area: this option, then, must be considered as having little future; indeed, $21.6 \%$ of the area dedicated to artichoke in the Valle del Guadalentín was lost between 2005 and 2010. For its part, option 3 is viable up to $0.17 € \cdot \mathrm{m}^{-3}$, which is more than is paid at the present time in Sardinia, although such an option would not be viable in south-eastern Spain.

\section{Conclusion}

The model could be applied to the socio-economic analysis of similar crops in different regions, serving as a tool for taking decisions related with water and agriculture, and for planning new irrigation systems or improving old ones. Different crops can be compared and analysed; whether or not it is worth following deficit irrigation strategies can be analysed by agricultural companies (microeconomics) and for planning and managing water resources at basin level and by water users associations, etc. Moreover, the model could serve to establish land uses and be useful in governance terms.

\section{REFERENCES}

[1] J. Canovas, "Análisis de los Diagnósticos Regionales Sobre Gestión de Recursos Hídricos Aplicados a Agricultura," Working Paper of Novagrimed Project (Programa MED Referencia CTE 1621), 2011.

[2] A. Millán, "Rentabilidad del Agua en los Cultivos más Representativos en la Cuenca del Segura," Consejería de Agricultura, Ganadería y Pesca, Murcia, 1988.

[3] J. G. García, "Evaluación Económica y Eficiencia del Agua de Riego en Frutales de Regadío," Consejería de Agricultura y Agua, Murcia, 2007.

[4] J. G. García and J. G. Brunton, "Eficiencia Económica del Agua de Riego en el Cultivo de Diferentes Grupos Varietales de Melocotón," Fruticultura Profesional, No. 172, 2008, pp. 128-139.

[5] T. M. De Jong, W. Tsuji, J. F. Doyle and Y. L. Grossman, "Comparative Economic Efficiency of Four Peach Production Systems in California," Hort Science, Vol. 34, No. 1, 1999, pp. 73-78.

[6] R. P. Marini and D. S. Sowers, "Peach Tree Growth, Yield and Profitability as Influenced by Tree for and Tree Density," Hort Science, Vol. 35, No. 5, 2000, pp. 837-842.

[7] P. R. Azorín, J. G. García and P. B. Ordaz, "Cost-Benefit Analysis of a Regulated Deficit-Irrigated Almond Orchard under Subsurface Drip Irrigation Conditions in South-Eastern Spain," Irrigation Science, Vol. 24, No. 3,
2006, pp. 175-184. doi:10.1007/s00271-005-0008-6

[8] J. G. García, A. Martínez and P. Romero, "Financial Analysis of Wine Grape Production Using Regulated Deficit Irrigation and Partial-Root Zone Drying Strategies," Irrigation Science, Vol. 30, No. 3, 2012, pp. 179-188. doi:10.1007/s00271-011-0274-4

[9] D. A. Goldhamer, M. Viveros and M. Salinas, "Regulated Deficit Irrigation in Almonds: Effects of Variations in Applied Water and Stress Timing on Yield and Yield Components," Irrigation Science, Vol. 24, No. 2, 2006, pp. 101-114. doi:10.1007/s00271-005-0014-8

[10] B. Dichio, C. Xiloyannis, A. Sofo and G. Montanaro, "Effects of Post-Harvest Regulated Deficit Irrigation on Carbohydrate and Nitrogen Partitioning, Yield Quality and Vegetative Growth of Peach Trees," Plant Soil, Vol. 290, No. 1-2, 2007, pp. 127-137. doi:10.1007/s11104-006-9144-x

[11] S. A. Alkhamisi, H. A. Abdelrahman, M. Ahmed and M. F. A. Goosen, "Assessment of Reclaimed Water Irrigation on Growth, Yield, and Water-Use Efficiency of Forage Crops," Applied Water Science, Vol. 1, No. 1-2, 2011, pp. 57-65. doi:10.1007/s13201-011-0009-y

[12] J. S. Neal, W. J. Fulkerson and B. G. Sutton, "Differences in Water-Use Efficiency among Perennial Forages Used by the Dairy Industry under Optimum and Deficit Irrigation," Irrigation Science, Vol. 29, No. 3, 2011, pp. 213232.

[13] I. Hussain, H. Turral, D. Molden and M. Ahmad, "Measuring and Enhancing the Value of Agricultural Water in Irrigated River Basins," Irrigation Science, Vol. 25, No. 3, 2007, pp. 263-282. doi:10.1007/s00271-007-0061-4

[14] R. Salvador, A. Martínez-Cob, J. Cavero and E. Playán, "Seasonal On-Farm Irrigation Performance in the Ebro Basin (Spain): Crops and Irrigation Systems," Agricultural Water Management, Vol. 98, No. 4, 2011, pp. 577 587. doi:10.1016/j.agwat.2010.10.003

[15] J. I. Macua, "New Horizons for Artichoke Cultivation. Proceedings of VI International Symposium on Artichoke, Cardoon and Their Wild Relatives," Acta Horticulturae, Vol. 730, 2007, pp. 39-48.

[16] R. Layard and S. Glaister, "Costs Benefit Analysis," Cambridge University Press, Cambridge, 1994, p. 497. doi:10.1017/CBO9780511521942

[17] E. Ballestero, "Economía de la Empresa," Alianza Editorial, Madrid, 2000, p. 416.

[18] J. G. García, P. Romero, P. Botía and F. García, "CostBenefit Analysis of Almond Orchard under Regulated Deficit Irrigation (RDI) in SE Spain," Spanish Journal of Agricultural Research, Vol. 2, No. 2, 2004, pp. 157-165.

[19] J. G. García, P. Romero, P. Botía and F. García, “Análisis Económico del Cultivo de Almendro en Riego Deficitario Controlado (RDC)," Fruticultura Profesional, Vol. 154, 2005, pp. 43-50.

[20] J. G. Pérez-Pérez, J. García, J. M. Robles and P. Botía, "Economic Analysis of Navel Orange cv. 'Lane late' Grown on Two Different Drought-Tolerant Rootstocks under Deficit Irrigation in South-Eastern Spain," Agricultural Water Management, Vol. 97, No. 1, 2010, pp. 157 - 
164. doi:10.1016/j.agwat.2009.08.023

[21] F. Alcón, M. D. de Miguel, J. A. Fernández and L. F. Condés, "Study of the Economic Viability of Artichoke Cultivations with Sexual or Vegetative Reproduction in Region of Murcia," Proceedings of 6th International Symposium on Artichoke, Cardoon and Their Wild Relatives, Acta Horticulturae, Vol. 730, 2007, pp. 465-471.

[22] D. Rigby, F. Alcón and M. Burton, "Supply Uncertainty and the Economic Value of Irrigation Water," European Review of Agricultural Economics, Vol. 37, No. 1, 2010, pp. 97-117. doi:10.1093/erae/jbq001

[23] D. A. Goldhamer, M. Salinas, C. Crisosto, K. R. Day, M. Soler and A. Moriana, "Effects of Regulated Deficit Irrigation and Partial Root Zone Drying on Late Harvest Peach Tree Perfomance," Acta Horticulturae, Vol. 592, 2002, pp. 343-350.

[24] L. H. Bassoi, B. F. Dantas, J. M. P. Lima, M. A. C. Lima, P. C. S. Leao, D. J. Silva, J. L. T. Maia, C. R. Souza, J. A. M. Silva and M. M. Ramos, "Preliminary Results of a Long-Term Experiment about RDI and PRD Irrigation Strategies in Wine Grapes in Sao Francisco Valley, Brasil," Acta Horticulturae, Vol. 754, 2007, pp. 275-282.

[25] E. Fereres, D. A. Goldhamer and L. R. Parsons, "Irrigation Water Management of Horticultural Crops," Hort Science, Vol. 38, No. 5, 2003, pp. 1036-1042.

[26] X. Cai, M. W. Rosegrant and C. Ringler, "Physical and Economic Efficiency of Water Use in the River Basin: Implications for Efficient Water Management," Water Resources Research, Vol. 39, No. 1, 2003, pp. 1013-1029.
doi:10.1029/2001WR000748

[27] M. M. Clop, L. Cots, M. Esteban and J. D. Barragán, "Rentabilidad Económica del Regadío de Los Canales de Urgell (Lleida, España)," Información Técnica Económica Agraria (ITEA), Vol. 105, No. 1, 2009, pp. 36-48.

[28] S. K. Jalota, A. Sood, J. D. Vitale and R. Srinivasan, "Simulated Crop Yields Response to Irrigation Water and Economic Analysis: Increasing Irrigated Water Use Efficiency in the Indian Punjab," Agronomy Journal, Vol. 99, No. 4, 2007, pp. 1073-1084. doi:10.2134/agronj2006.0054

[29] A. Ward and M. Ari, "The Economic Value of Water in Agriculture: Concepts and Policy Applications," Water Policy, Vol. 4, No. 5, 2002, pp. 423-446. doi:10.1016/S1366-7017(02)00039-9

[30] P. J. G. J. Hellegers, R. Soppe, C. J. Perry and W. G. M. Bastiaanssen, "Combining Remote Sensing and Economic Analysis to Support Decisions that Affect Water Productivity," Irrigation Science, Vol. 27, No. 3, 2009, pp. 243-251. doi:10.1007/s00271-008-0139-7

[31] EEC, "Hacia un Sector Vitivinícola Europeo," Informe de la Comisión Europea, 2006. http://ec.europa.eu/spain/pdf/sectorvitivinicola_es.pdf,

[32] CES (Consejo Económico y Social de Murcia), "Informe Sobre la Situación Hidrológica y Socioeconómica en la Cuenca del Segura en el Nuevo Contexto del Plan Hidrológico Nacional," 2000. http://www.cesmurcia.org/informes/a_2000/phn/2-2000.p df 